\title{
PENGARUH SUMBER DAYA MANUSIA TERHADAP PENGENDALIAN MUTU JALAN (Studi kasus di Propinsi DIY)
}

\author{
Oleh: Rossy Armyn Machfudiyanto ${ }^{1}$ \\ E-mail: rossyarmyn@gmail.com
}

\begin{abstract}
ABSTRAK: Pengendalian mutu jalan dalam kaitannya dengan pengaruh sumber daya manusia yang ada, sangat membutuhkan perilaku manusia dalam kaitannya dengan berbagai situasi di lingkungan jalan. Variabel pengaruh dalam penelitian ini meliputi tingkat pendidikan, jenis kelamin, umur, tingkat pendidikan non formal, potensi, kompetensi, perilaku, latihan, kedisiplinan, kesehatan dan pengalaman kerja.
\end{abstract}

Tujuan dari penelitian ini adalah untuk mengetahui bobot prioritas variabel-variabel pengaruh yang mempengaruhi sumber daya manusia dalam mengendalikan mutu jalan yang meliputi pembangunan, peningkatan dan pemeliharaan jalan. Penelitian ini menggunakan data primer yang diperoleh dari hasil survai. Survai dilakukan dengan metode kuesioner yang disebarkan oleh para ahli yang berkompeten di bidang pengendalian mutui jalan.

Penelitian ini menggunakan dua metode yaitu dengan metode Analisis Faktor dan metode AHP. Untuk metode Analisis Faktor bertujuan untuk mereduksi variabel pengaruh SDM yang terbentuk. Hasil penelitian diperoleh dari sebelas variabel pengaruh SDM yang terbentuk yang kemudian diseleksi menggunakan metode Analisis Faktor didapatkan sembilan variabel pengaruh SDM terseleksi yang telah dikelompokkan menjadi tiga faktor yaitu pendidikan formal, perilaku pengalaman kerja.

Hasil penelitian dengan metode AHP diperoleh bobot prioritas masing-masing kriteria terhadap tujuan SDM untuk mengendalikan mutu jalan yaitu Pendidikan formal $=32,9 \%$, Perilaku $=27,7 \%$, Pengalaman kerja $=39,4 \%$. Pembobotan alternatif dalam pengendalian mutu jalan yang meliputi pembangunan jalan, peningkatan jalan, pemeliharaan jalan ditinjau dari variabel pengaruh SDM yang terseleksi diperoleh hasil yang hampir sama akan tetapi bobot prioritas yang terbesar terdapat pada pembangunan jalan sebesar 34,5\% diikuti dengan peningkatan jalan sebesar 33,3\% dan pemeliharaan jalan sebesar 32,2\%.

Kata Kunci : Variabel Pengaruh SDM, Mutu Jalan, AHP, Analisa Faktor

\section{PENDAHULUAN}

\subsection{Latar Belakang}

Pengaturan dan pengendalian lalu lintas telah berkembang pesat sejalan dengan perkembangan sumber daya manusia yang ada. Pengembangan sumber daya manusia adalah proses transformasi potensi manusia menjadi kekuatan efektif untuk mencapai tujuan tertentu. Selain itu manusia merupakan sumber daya yang paling bernilai, dan ilmu perilaku menyiapkan banyak teknik dan program yang dapat menuntun pemanfaatan sumber daya manusia secara lebih efektif. Mengingat pentingnya peranan manusia dalam pengaruhnya terhadap jalan khususnya pengendalian mutu jalan, maka pengembangan sumber daya manusia dimulai dari karakteristik individu yang baik, karena ini sangat menentukan sumber daya manusia yang ada

\subsection{Manfaat Penelitian}

Manfaat yang dapat diambil dari penelitian ini adalah penulis dapat menentukan variabel-variabel pengaruh sumber daya manusia terhadap pengendalian mutu jalan dengan berdasarkan hasil pembobotan dari perbandingan antar kriteria maupun

1) adalah staf pengajar Program Studi Teknik Sipil Universitas Cokroaminoto Yogyakarta

72 Pengaruh Sumber Daya Manusia Terhadap Pengendalian Mutu Jalan (Studi Kasus di Provinsi DIY) (Rossy Armyn Machfudiyanto) 
alternatif pengendalian mutu jalan yang meliputi pembangunan, peningkatan maupun pemeliharaan jalan. Selain itu juga hasil penelitian ini dapat memberikan gambaran kepada para pengelola dinas-dinas terkait tentang karakteristik sumber daya manusia serta pengaruhnya terhadap pengendalian mutu jalan. Gambaran ini diharapkan dapat dipakai sebagai bahan informasi dalam pengambilan keputusan untuk pengembangan sumber daya manusia di masa yang akan datang.

\subsection{Tujuan Penelitian}

Tujuan penelitian ini yaitu untuk mengetahui bobot prioritas variabel pengaruh (kriteria) SDM yang terseleksi dan bobot prioritas antar alternatif dalam mengendalikan mutu jalan ditinjau dari variabel pengaruh (kriteria) SDM yang terseleksi

\section{BATASAN MASALAH}

Penelitian ini dibatasi pada :

Variabel pengaruh dalam sumber daya manusia yang digunakan meliputi tingkat pendidikan formal, jenis kelamin, umur, tingkat pendidikan non formal, potensi, kompetensi, perilaku, latihan, kedisiplinan, kesehatan dan pengalaman kerja, Pemilihan jalan yang digunakan dalam penelitian yaitu jalan propinsi, Penetapan para pengambil keputusan berdasarkan keahlian pada bidang yang terkait dengan penelitian ini, Wilayah yang digunakan untuk penelitian ini adalah Propinsi DIY.

\section{TINJAUAN PUSTAKA}

Pembangunan Jalan adalah kegiatan pemrograman dan penganggaran, perencanaan teknis, pelaksanaan konstruksi, serta pengoperasian dan pemeliharaan jalan. Pemeliharaan jalan merupakan kegiatan yang dilaksanakan secara berencana sesuai dengan kebutuhan agar jalan dapat berperan seperti yang diperhitungkan. Pemeliharaan jalan meliputi kegiatan penanganan berupa perawatan, rehabilitasi, penunjangan dan peningkatan jalan sedangkan peningkatan jalan merupakan kegiatan yang dilaksanakan secara berencana untuk memperoleh kualitas jalan yang lebih terjamin, baik dari segi fisik maupun dari segi manajemen.

\subsection{Manusia dan Decision Making}

Menurut Saaty (1971) dalam Permadi (1992), manusia selalu dihadapkan dengan masalah pengambilan keputusan baik yang penting maupun yang tidak penting.Bagaimanapun tidak pentingnya suatu masalah pengambil keputusan, otak manusia tetap melakukan suatu proses tertentu sampai didapatkan sebuah keputusan pasti. Proses pengambilan keputusan dalam otak manusia pada dasarnya memilih suatu kriteria ve dari sekian banyak riteria ve berdasarkan sejumlah riteria dari suatu permasalahan

\subsection{Hirarki}

Hirarki adalah alat yang paling mudah untuk memahami masalah yang kompleks dimana masalah tersebut diuraikan ke dalam elemen-elemen yang bersangkutan, menyusun elemen-elemen tersebut secara hirarkis dan akhirnya melakukan penilaian atas elemen-elemen tersebut sekaligus menentukan keputusan apa yang diambil.

\subsection{Karakteristik Umum Model Analitical Hierarchy Process}

Kelebihan Model AHP adalah kemampuannya memecahkan masalah yang multiobjectives dan multicriteria, model AHP ini lebih disebabkan oleh fleksibilitasnya yang tinggi terutama dalam pembuatan hirarkinya, sifat fleksibel tersebut dapat menangkap beberapa tujuan dan kriteria sekaligus dalam sebuah model atau sebuah hirarki, dapat memecahkan masalah yang mempunyai tujuan-tujuan yang saling berlawanan dan bentuknya sederhana. Kelemahan Model AHP adalah apabila seseorang memberikan penilaian yang keliru, maka hasil akhir dari model ini menjadi tidak ada artinya, karena 
ketergantungan model ini pada input seseorang akan membuat hasil akhir. Kemudian seseorang akan ragu-ragu dalam menanggapi solusi yang dihasilkan model ini, jika belum adanya kriteria yang jelas.

\subsection{Keaslian Penelitian}

Pengaruh sumber daya manusia terhadap pengendalian mutu jalan, pada saat ini belum di teliti. Untuk proses pemilihan dengan menggunakan metode AHP telah diteliti oleh Satriawan (2001), mengenai Tinjauan Berbagai Alternatif Jalur Trem Listrik di Yogyakarta, dan Rostianti (2001), mengenai Penetapan Kebijakan dalam Alternatif Pemilihan Jalur Lintas Selatan dengan lokasi kasus Jalur Lintas Selatan Propinsi DIY. Penelitian ini mempunyai dasar teori yang sama dengan penelitian sebelumnya yaitu menggunakan metode Analytical Hierarchy Process (AHP), akan tetapi pada penelitian ini membahas tentang pengaruh sumber daya manusia terhadap pengendalian mutu jalan di propinsi DIY. Perbedaan penelitian ini dengan sebelumnya yaitu sebelum menggunakan teori AHP, pada penelitian ini untuk mereduksi variabel pengaruh SDM yang terbentuk menggunakan landasan teori Analisa Faktor sehingga diperoleh faktor baru yang akan digunakan pada metode AHP. Pada teori AHP, peneliti menggunakan skala 1 sampai dengan 9 yang dinamakan skala perbandingan.

\section{LANDASAN TEORI}

\subsection{Metode Analytical Hierarchy Process}

Menurut Saaty (1990), Analytical Hierarchi Process Method (AHP) merupakan dasar untuk membuat suatu keputusan, yang didesain dan dilakukan secara rasional dengan membuat penyeleksian yang terbaik terhadap beberapa alternatif yang dievaluasi dengan multikriteria. Dalam proses ini, para pembuat keputusan mengabaikan perbedaan kecil dalam pengambilan keputusan dan selanjutnya mengembangkan seluruh prioritas untuk membuat rangking prioritas dari beberapa alternatif. Dalam AHP dikenal adanya keputusan yang konsisten dan keputusan yang tidak konsisten.

\subsection{Menetapkan Prioritas}

Dalam menetapkan prioritas elemen-elemen suatu persoalan keputusan yaitu dengan membuat pembandingan berpasangan. Elemen-elemen dibandingkan berpasangan terhadap suatu kriteria yang ditentukan. Untuk itu, matriks merupakan solusi yang paling tepat untuk menyelesaikan permasalahan ini. Matrik merupakan alat yang sederhana dan mudah digunakan selain itu juga memberikan kerangka untuk menguji konsistensi, memperoleh informasi tambahan dengan jalan membuat segala perbandingan yang mungkin dan menganalisis prioritas menyeluruh terhadap perubahan dalam judgment.

Tabel 1 Skala perbandingan

\begin{tabular}{|c|l|}
\hline Angka & \multicolumn{1}{|c|}{ Definisi } \\
\hline 1 & Sama pentingnya \\
\hline 3 & Sedikit lebih penting \\
\hline 5 & Lebih penting \\
\hline 7 & Sangat lebih penting \\
\hline 9 & Mutlak lebih penting \\
\hline $2,4,6,8$ & Tingkat kepentingan diantara angka-angka tersebut diatas \\
\hline
\end{tabular}

Sumber : Saaty (1990)

74 Pengaruh Sumber Daya Manusia Terhadap Pengendalian Mutu Jalan (Studi Kasus di Provinsi DIY) (Rossy Armyn Machfudiyanto) 


\subsection{Pembobotan Elemen}

Pada dasarnya formulasi matematis pada multikriteria dengan metode AHP dilakukan dengan menggunakan metode matrik.

\begin{tabular}{c|cccc} 
& $\mathrm{A}_{1}$ & $\mathrm{~A}_{2}$ & $\cdots$ & $\mathrm{A}_{n}$ \\
\hline $\mathrm{A}_{1}$ & $a_{11}$ & $a_{12}$ & $\cdots$ & $a_{1 n}$ \\
$\mathrm{~A}_{2}$ & $a_{21}$ & $a_{22}$ & $\cdots$ & $a_{2 n}$ \\
$\vdots$ & $\vdots$ & $\vdots$ & $\cdots$ & $\vdots$ \\
$\mathrm{A}_{n}$ & $a_{n 1}$ & $a_{n 2}$ & $\cdots$ & $a_{n n}$
\end{tabular}

Matrik Anxn merupakan matrik resiprokal. Dan diasumsikan terdapat $\mathrm{n}$ elemen, yaitu $\mathrm{W}_{1}, \mathrm{~W}_{2}, \ldots, \mathrm{W}_{\mathrm{n}}$ yang akan dinilai secara perbandingan. Nilai (judgement) perbandingan secara berpasangan antara (Wi, Wj)dapat dipresentasikan seperti matrik tersebut.

$$
\frac{W i}{W j}=a(i, j) ; i, j=1,2, \ldots, n
$$

Dalam hal ini matrik perbandingan adalah matrik dengan unsur-unsurnya adalah $a_{i j}$ dengan $\mathrm{i}, \mathrm{j}=1,2,3, \ldots, \mathrm{n}$. Unsur-unsur matrik tersebut diperoleh dengan membandingkan satu elemen operasi terhadap elemen operasi lainnya untuk tingkat hirarki yang sama. Misalnya unsur $\mathrm{a}_{11}$ adalah perbandingan kepentingan elemen operasi A1 dengan elemen operasi A1 sendiri.Sehingga dengan sendirinya nilai unsur $a_{11}$ adalah sama dengan 1 . Cara yang sama maka diperoleh semua unsur diagonal matrik perbandingan sama dengan 1.

\begin{tabular}{c|cccc} 
& $\mathrm{A}_{1}$ & $\mathrm{~A}_{2}$ & $\cdots$ & $\mathrm{A}_{n}$ \\
\hline $\mathrm{A}_{1}$ & 1 & & & \\
$\mathrm{~A}_{2}$ & & 1 & & \\
$\vdots$ & & & 1 & \\
$\mathrm{~A}_{n}$ & & & & 1
\end{tabular}

Nilai unsur $\mathrm{a}_{12}$ adalah perbandingan kepentingan elemen operasi $\mathrm{A} 1$ terhadap elemen operasi $A 2$. Besarnya nilai $a_{21}$ adalah $1 / a_{12}$ yang menyatakan tingkat intensitas kepentingan elemen operasi A2 terhadap elemen operasi A1. Matrik perbandingan preferensi tersebut diolah dengan melakukan perhitungan pada tiap baris matrik tersebut dengan menggunakan persamaan 3.3

$$
W i=\sqrt[n]{a_{i 1} x a_{i 2} x a_{i 3} x \ldots x a_{i j}}
$$

Perhitungan dilanjutkan dengan memasukkan nilai Wi pada matrik hasil perhitungan tersebut ke persamaan dibawah ini.

$$
X i=\frac{W i}{\sum W i}
$$




\subsection{Konsistensi}

Rumus dari indeks konsistensi adalah:

$$
C I=\frac{(\lambda m a k s-n)}{(n-1)}
$$

Dimana $\lambda$ maks merupakan eigenvalue dan $\mathrm{n}$ ukuran matrik.

Indeks konsistensi kemudian diubah dalam bentuk rasio inkonsistensi dengan cara membaginya dengan suatu indeks random. Hasilnya menunjukkan bahwa makin besar ukuran matrik, maka makin tinggi tingkat inkonsistensi yang dihasilkan.

Tabel 2 Nilai Indeks Random

\begin{tabular}{|c|c|}
\hline Ukuran Matrik & Indeks Random (inkonsisten) \\
\hline 1 & 0,00 \\
2 & 0,00 \\
4 & 0,58 \\
5 & 0,90 \\
6 & 1,12 \\
7 & 1,24 \\
8 & 1,32 \\
9 & 1,41 \\
10 & 1,45 \\
11 & 1,49 \\
12 & 1,51 \\
13 & 1,48 \\
14 & 1,56 \\
15 & 1,57 \\
\hline
\end{tabular}

Sumber : Saaty (1990)

Perbandingan antar $\mathrm{Cl}$ dan $\mathrm{RI}$ untuk suatu matrik didefinisikan sebagai Rasio Konsisten $(\mathrm{CR})$.

$$
C R=\frac{C I}{R I}
$$

Untuk model AHP, matrik perbandingan dapat diterima jika nilai rasio konsistensi $\mathrm{CR}<0,1$. Lebih dari itu harus ada revisi penilaian karena tingkat inkonsistensi yang terlalu besar dapat menjurus pada suatu kesalahan.

\subsection{Analisa Faktor}

Analisa Faktor yaitu metode yang digunakan untuk mengidentifikasi variabel dasar atau faktor yang menerangkan pola hubungan dalam suatu himpunan variabel observasi. Analisa Faktor sering digunakan pada reduksi data untuk mengidentifikasi suatu jumlah kecil faktor yang menerangkan beberapa faktor yang mempunyai kemiripan karakter. Tujuan reduksi data untuk mengeliminasi variabel independent yang saling berkorelasi sehingga akan diperoleh jumlah variabel yang lebih sedikit dan tidak berkorelasi. Variabelvariabel yang saling berkorelasi mungkin mempunyai kesamaan karakter dengan variabel lainnya sehingga dapat dijadikan menjadi satu faktor.

76 Pengaruh Sumber Daya Manusia Terhadap Pengendalian Mutu Jalan (Studi Kasus di Provinsi DIY) (Rossy Armyn Machfudiyanto) 


\section{METODOLOGI PENELITIAN}

\subsection{Variabel Pengaruh Human Resources}

Penelitian ini bertujuan untuk mengetahui kriteria-kriteria yang ada dalam perilaku Sumber Daya Manusia yang mempengaruhi terhadap pengendalian mutu jalan. Variabelvariabel yang mempengaruhi karakteristik Sumber Daya Manusia antara lain:

1. Tingkat pendidikan formal adalah pendidikan yang diakui legalitasnya oleh pemerintah dan berpengaruh terhadap produktivitas kerja (Koster, 2001).

2. Tingkat pendidikan non formal adalah pendidikan yang langsung diselenggarakan oleh perusahaan atau instansi tertentu (Koster, 2001).

3. Jenis kelamin, akan menentukan daya dan kecepatan reaksi terhadap suatu rangsangan yang diterima. Peran wanita dalam pengambilan keputusan semakin besar. Hasil penelitian berpendapat bahwa kini semakin besar porsi wanita yang memegang posisi sebagai pemimpin. Bahkan perubahan perilaku ke arah perilaku yang sebelumnya merupakan pekerjaan pria semakin menonjol (Ancok, 2004)

4. Umur adalah indeks yang menempatkan individu dalam urutan perkembangan. Untuk orang yang berpendidikan lebih baik cenderung lebih panjang hidupnya daripada mereka yang terbatas pendidikannya (Hurlock, 1991)

5. Perilaku merupakan sesuatu yang dapat mengenai banyak pengaruh dari lingkungan atau keadaan sekitarnya (Walgito, 1990).

6. Kompetensi adalah kewenangan seseorang untuk menentukan atau memutuskan suatu hal (Poerwadarminta, 1982).

7. Potensi adalah sesuatu bakat alamiah yang dapat mempengaruhi kemampuan (ability) yang terdapat pada manusia (Poerwadarminta, 1982).

8. Latihan (Training) adalah kegiatan yang dilakukan atau dipelajari oleh manusia sehingga dapat berguna baik untuk diri sendiri maupun orang lain dan akan memupuk pertumbuhan kepribadian hidup berkomunitas (Ancok, 2004).

9. Kedisiplinan bertujuan untuk membentuk perilaku sedemikian rupa sehingga akan sesuai dengan peran-peran yang ditetapkan dan merupakan syarat mutlak untuk mencapai impian atau melaksanakan misi hidup sehingga menemukan arah dan tujuan hidup yang jelas (Hurlock, 1978)

10. Kesehatan adalah keadaan sehat baik jasmani maupun rohani dan sejahtera dari jiwa dan sosial yang memungkinkan setiap orang hidup secara sosial dan ekonomis (Undang-Undang No.23 Tahun 1992 Tentang Kesehatan)

11. Pengalaman kerja, varibel ini juga penting guna menunjang kualitas atau kemampuan sumber daya manusia, karena pengalaman kerja bersumber dari dalam diri manusia itu sendiri yang berinteraksi dengan kebijakan suatu instansi tertentu (Koster, 2001).

\subsection{Penentuan Jumlah Responden}

Dalam penelitian ini, penulis mendapatkan responden dari hasil sensus yang dilakukan BPS Propinsi DIY. Diperoleh jumlah responden yang berkaitan dengan penelitan ini yaitu Dinas Pekerjaan Umum di seluruh Propinsi DIY dengan pendidikan minimal SLTA atau sederajat dan Dosen Teknik Sipil seluruh perguruan tinggi di Propinsi DIY sebanyak 794 orang

Dengan metode pengambilan sampel acak sederhana maka diperoleh jumlah responden yang diinginkan dengan tingkat kepercayaan $100 \%$ maka ukuran sampel yang harus diambil adalah:

Ukuran sampel $(\mathrm{n})=\frac{N Z^{2} S^{2}}{N d^{2}+Z^{2} S^{2}}$ 
Dengan, $\quad \mathrm{N}$ : Total banyaknya sampling $=794$ orang

Z : Variabel Normal, untuk $100 \%$ mendekati 3,0

$S: p(1-p)$ dengan, $p=10 \%$

$\mathrm{d}$ : Besarnya toleransi penyimpangan $=0,10$

Diperoleh ukuran sampel $(\mathrm{n})=\frac{794 \times 3 \times 3 \times 0,1 \times(1-0,1)}{(794 \times 0,1 \times 0,1)+(3 \times 3 \times 0,1(1-0,1))}$

$$
=\frac{643,14}{8,75}=73,502 \text { dibulatkan } 74 \text { orang }
$$

Sehingga jumlah responden yang diperlukan dalam survai pertama yaitu 74 orang.

Sedangkan untuk jumlah responden untuk survai kedua diperoleh hasil

Ukuran sampel $(\mathrm{n})=\frac{N Z^{2} S^{2}}{N d^{2}+Z^{2} S^{2}}$

Dengan, $\quad \mathrm{N}$ : Total banyaknya sampling $=74$ orang

Z : Variabel Normal, untuk $100 \%$ mendekati 3,0

$S: p(1-p)$ dengan, $p=5 \%$

$\mathrm{d}$ : Besarnya toleransi penyimpangan $=0,10$

Diperoleh ukuran sampel $(\mathrm{n})=\frac{74 \times 3 \times 3 \times 0,05 \times(1-0,05)}{(74 \times 0,1 \times 0,1)+(3 \times 3 \times 0,05(1-0,05))}$

$$
=\frac{31,635}{1,17}=27,04 \text { dibulatkan } 30 \text { orang }
$$

Sehingga jumlah responden yang diperlukan dalam survai kedua yaitu 30 orang.

\subsection{Penentuan Responden}

Dalam penelitian ini responden yang diminta pendapatnya melalui kuesioner antara lain berasal dari:

1. Jurusan Teknik Sipil FT UGM $=4$ orang/2 orang

2. Jurusan Teknik Sipil FTSP UII Yogyakarta $=4$ orang/2 orang

3. Jurusan Teknik Sipil FT UMY $=4$ orang/2 orang

4. Program Studi Sipil FT UAJY $=4$ orang/2 orang

5. Jurusan Teknik Sipil STTNAS Yogyakarta $=4$ orang $/ 2$ orang

6. PT. Puserbumi (Konsultan) $=5$ orang $/ 2$ orang

7. PT. Firama Citra Utama (Konsultan) $=5$ orang/2 orang

8. PT. Perwita Karya (Kontraktor) $=5$ orang $/ 2$ orang

9. PT. Adhi Karya (Kontraktor) $=5$ orang $/ 2$ orang

10. Dinas Kimpraswil Bidang Bina Marga Propinsi DIY $=14$ orang/2 orang

11. Dinas Pekerjaan Umum Kab. Bantul Propinsi DIY $=4$ orang/2 orang

12. Dinas Pekerjaan Umum Kab. Kulonprogo Propinsi DIY $=4$ orang/2 orang

13. Dinas Pekerjaan Umum Kab. Sleman Propinsi DIY $=4$ orang/2 orang

14. Dinas Pekerjaan Umum Kab. Gunungkidul Propinsi DIY $=4$ orang/2 orang

15. Dinas Pekerjaan Umum Kota Yogyakarta Propinsi DIY $=4$ orang/2 orang

\subsection{Pengumpulan Data}

78 Pengaruh Sumber Daya Manusia Terhadap Pengendalian Mutu Jalan (Studi Kasus di Provinsi DIY) (Rossy Armyn Machfudiyanto) 
Penelitian yang dilaksanakan adalah untuk mengetahui kriteria-kriteria pada Sumber Daya Manusia yang dapat mempengaruhi terfadap pengendalian mutu jalan. Data yang diperoleh dalam penelitian ini antara lain data primer dan data sekunder. Data Primer yaitu data yang didapatkan dari hasil wawancara dan pengisian kuesioner dengan para responden ahli. Data Sekunder yaitu data yang didapatkan dari hasil studi dan literature dari buku-buku referensi maupun Journal yang terkait dengan penelitian ini.

\subsection{Langkah Penelitian}

Langkah-langkah dalam penelitian ini yaitu: tahap perumusan masalah, tahap studi literature dan pengumpulan data, survei i untuk mengelompokkan variabel, tahap analisa faktor, survei ii untuk mencari prioritas variabel pengaruh SDM, tahap analitical hierarchy process, tahap pembobotan kriteria dan alternatif.

\section{HASIL ANALISIS DAN PEMBAHASAN}

\subsection{Proses Seleksi Variabel Pengaruh SDM}

\subsubsection{Inputing Data Responden}

Hasil kuesioner yang telah disebarkan kepada ahli terkait (stakeholders) dianalisis dengan menggunakan analisis faktor, dimana setiap variabel atau pernyataan yang diajukan kepada responden akan diberi tanda antara angka 1 sampai 5. dengan demikian skala untuk pengukuran persepsi ini adalah menggunakan Skala Interval.

\subsubsection{Uji Korelasi}

Tabel 3 KMO and Bartlett's test pada variabel pengaruh SDM

\begin{tabular}{|l|l|r|}
\hline \multicolumn{2}{|l|}{ Kaiser-Meyer-Olkin Measure of Sampling Adequacy. } &, 563 \\
\hline Bartlett's Test of Sphericity & Approx. Chi-Square & 140,222 \\
\hline & Df & 55 \\
\hline & Sig. &, 000 \\
\hline
\end{tabular}

Pada Tabel 3 terlihat bahwa nilai KMO MSA adalah 0,563 dan signifikasi 0, maka proses analisis dapat dilanjutkan. Dari hasil tersebut dapat dilihat bahwa variabel yang memiliki nilai MSA kurang dari 0,5 adalah variabel Tingkat Pendidikan Non Formal dan Jenis Kelamin dengan nilai berturut-turut 0,464 dan 0,468. yang pertama kali harus dikeluarkan adalah variabel yang memiliki nilai $M S A$ paling kecil, yaitu variabel Tingkat Pendidikan Non Formal dan kemudian dilakukan uji korelasi lanjutan.

Tabel $4 \mathrm{KMO}$ and Bartlett's test pada variabel pengaruh SDM pada uji lanjutan

\begin{tabular}{|l|l|r|}
\hline \multicolumn{2}{|l|}{ Kaiser-Meyer-Olkin Measure of Sampling Adequacy. } &, 588 \\
\hline Bartlett's Test of Sphericity & Approx. Chi-Square & 116,026 \\
\hline & Df & 45 \\
\hline & Sig &, 000 \\
\hline &. & \\
\hline
\end{tabular}

Nilai KMO MSA adalah 0,588 dan nilai signifikasi tetap memenuhi syarat yaitu 0 $(<0,05)$ sehingga proses dapat dilanjutkan. Pada Tabel 5.4 hasil pengujian ulang matrik Anti Image variabel pengaruh SDM terlihat bahwa variabel dengan nilai MSA kurang dari 0,5 adalah variabel Jenis Kelamin dan Umur yang nilainya 0,494 dan 0,486. yang harus dikeluarkan adalah variabel yang memiliki $M S A$ nya paling kecil, yaitu variabel Umur 
Tabel 5 KMO and Bartlett's test pada variabel pengaruh SDM pada uji lanjutan

\begin{tabular}{|l|l|r|}
\hline \multicolumn{2}{|c|}{ Kaiser-Meyer-Olkin Measure of Sampling Adequacy. } &, 634 \\
\hline Bartlett's Test of Sphericity & Approx. Chi-Square & 88,435 \\
\hline & Df & 36 \\
\hline & Sig. &, 000 \\
\hline
\end{tabular}

Pada Tabel 5.5 terlihat bahwa nilai KMO MSA adalah 0,634 dan signifikasi 0 $(<0,05)$ sehingga proses dapat dilanjutkan. Pada Tabel 5.6 hasil pengujian ulang matrik Anti Image variabel pengaruh SDM terlihat bahwa sudah tidak ada lagi variabel yang memiliki nilai $M S A$ kurang dari 0,5 . dengan demikian tidak ada lagi variabel yang harus dikeluarkan.

\subsubsection{Uji Ekstraksi}

Pada variabel Tingkat Pendidikan Formal terdapat angka 0,584 berarti sebesar $58,4 \%$ varian variabel Tingkat Pendidikan Formal dapat dijelaskan oleh faktor yang terbentuk. Demikian seterusnya untuk variabel pengaruh SDM lainnya.

Tabel 6 Hasil Uji Ekstraksi

\begin{tabular}{|l|c|c|}
\hline Variabel Pengaruh SDM & Initial & Extraction \\
\hline Tingkat Pendidikan Formal & 1.000 & .584 \\
\hline Jenis Kelamin & 1.000 & .591 \\
\hline Perilaku & 1.000 & .642 \\
\hline Kompetensi & 1.000 & .633 \\
\hline Potensi & 1.000 & .560 \\
\hline Kedisiplinan & 1.000 & .445 \\
\hline Latihan (Training) & 1.000 & .581 \\
\hline Kesehatan & 1.000 & .569 \\
\hline Pengalaman Kerja & 1.000 & .572 \\
\hline
\end{tabular}

\subsubsection{Factoring dan Rotation}

Dari penyeleksian variabel diatas diperoleh hasil bahwa ada 9 variabel pengaruh SDM yang digunakan dalam analisis faktor. Tiap variabel mempunyai varian 1 sehingga total varian dari 9 variabel tersebut adalah $9 \times 1=9$. Pada kolom Extraction Sums of Squared Loading terdapat 3 baris angka. Jika dari 9 variabel dijadikan 1 faktor, maka faktor yang terbentuk dapat menjelaskan varian dari 9 variabel sebesar 24,399\%. Persentase ini diperoleh dari : $\frac{2,196}{9} \times 100 \%=24,399 \%$

Pada bagian Initial Eigenvalues di kolom Total, ada 3 angka yang nilainya lebih besar dari 1. hal ini berarti ada 3 faktor yang terbentuk karena banyaknya angka dengan nilai diatas 1 yang digunakan untuk menghitung faktor yang terbentuk. Nilai tersebut selalu urut mulai yang terbesar. Jika angka-angka tersebut dijumlahkan, maka akan diperoleh total varian dari 9 variabel, yaitu $2,196+1,669+1,312+0,896+0,717+0,625+0,594+0,548+$ $0,443=9$.

80 Pengaruh Sumber Daya Manusia Terhadap Pengendalian Mutu Jalan (Studi Kasus di Provinsi DIY) (Rossy Armyn Machfudiyanto) 
Tabel 7 Total Variance Explained Variabel Pengaruh SDM

\begin{tabular}{|c|c|c|c|c|c|c|}
\hline \multirow{2}{*}{$\begin{array}{c}\text { Compo } \\
\text { nent }\end{array}$} & \multicolumn{3}{|c|}{ Initial Eigenvalues } & \multicolumn{3}{c|}{ Extraction Sums of Squared Loadings } \\
\cline { 2 - 7 } & Total & \% of Variance & Cumulative \% & Total & \% of Variance & Cumulative \% \\
\hline 1 & 2.196 & 24.399 & 24.399 & 2.196 & 24.399 & 24.399 \\
\hline 2 & 1.669 & 18.546 & 42.945 & 1.669 & 18.546 & 42.945 \\
\hline 3 & 1.312 & 14.576 & 57.522 & 1.312 & 14.576 & 57.522 \\
\hline 4 & .896 & 9.951 & 67.472 & & & \\
\hline 5 & .717 & 7.967 & 75.440 & & & \\
\hline 6 & .625 & 6.948 & 82.387 & & & \\
\hline 7 & .594 & 6.603 & 88.990 & & & \\
\hline 8 & .548 & 6.092 & 95.082 & & & \\
\hline 9 & .443 & 4.918 & 100.000 & & & \\
\hline
\end{tabular}

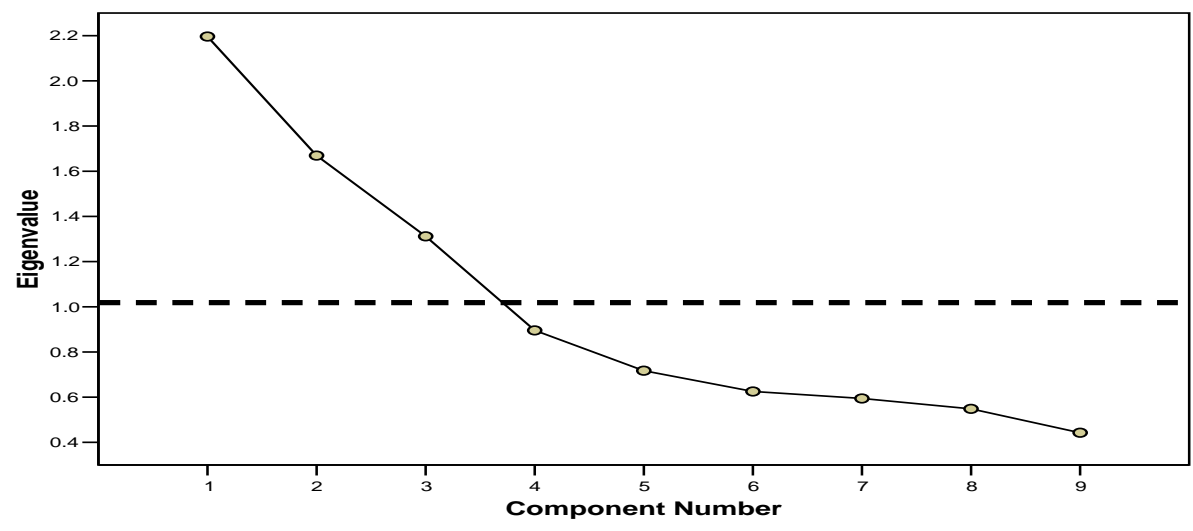

Gambar 1 Scree Plot Variabel Pengaruh SDM

Pada Total Variance Explained dan Scree Plot diperoleh hasil bahwa ada 3 faktor yang terbentuk untuk mereduksi 9 variabel. Pada tabel tersebut terdapat 3 komponen. Angka yang ada merupakan factor loading yang menunjukan korelasi antara suatu variabel dengan faktor yang terbentuk.

Tabel 8 Component Matrix Variabel Pengaruh SDM

\begin{tabular}{|l|c|c|c|}
\hline \multicolumn{1}{|c|}{ Variabel pengaruh SDM } & \multicolumn{3}{c|}{ Component } \\
\hline Tingkat Pendidikan Formal & 1 & 2 & 3 \\
\hline Jenis Kelamin & .083 & .574 & .497 \\
\hline Perilaku & .348 & .499 & .470 \\
\hline Kompetensi & .298 & .403 & -.625 \\
\hline Potensi & .536 & .428 & -.403 \\
\hline Kedisiplinan & .674 & .286 & -.158 \\
\hline Latihan (Training) & .354 & -.542 & -.162 \\
\hline Kesehatan & .554 & -.307 & .423 \\
\hline Pengalaman Kerja & .565 & -.495 & -.067 \\
\hline
\end{tabular}


Pada variabel Tingkat Pendidikan Formal, korelasi variabel ini dengan faktor 1 adalah 0,083 korelasi dengan faktor 2 adalah 0,574 dan korelasi dengan faktor 3 adalah 0,497 . demikian seterusnya. Jika diperhatikan, masih ada factor loading yang kurang dari 0,5 sehingga variabel tersebut tidak bisa dimasukkan kedalam faktor 1,2 maupun 3 . Untuk menyelesaikannya digunakan metode rotasi.

Dari hasil pemilihan analisis faktor dengan metode ekstrasi tampak bahwa masih terdapat beberapa variabel yang belum dapat dimasukkan dalam satu faktor tertentu. Dengan cara yang hampir sama dengan analisis faktor seperti sebelumnya, hasilnya terdapat pada Tabel 12 dan Tabel 5.13

Tabel 9 Hasil Analisis Faktor dengan Metode Rotasi

\begin{tabular}{|l|c|c|c|}
\hline Variabel pengaruh SDM & \multicolumn{3}{|c|}{ Component } \\
\hline $\begin{array}{l}\text { Tingkat Pendidikan } \\
\text { Formal }\end{array}$ & -.078 & .015 & .760 \\
\hline Jenis Kelamin & .165 & .145 & .736 \\
\hline Perilaku & -.158 & .778 & -.103 \\
\hline Kompetensi & .088 & .783 & .111 \\
\hline Potensi & .345 & .631 & .208 \\
\hline Kedisiplinan & .514 & .032 & -.425 \\
\hline Latihan (Training) & .731 & -.114 & .182 \\
\hline Kesehatan & .687 & .115 & -.288 \\
\hline Pengalaman Kerja & .720 & .156 & .170 \\
\hline
\end{tabular}

Tabel 10 Component Transformation Matrix

\begin{tabular}{|c|c|c|c|}
\hline Component & 1 & 2 & 3 \\
\hline 1 & .802 & .569 & .180 \\
\hline 2 & -.514 & .506 & .693 \\
\hline 3 & .304 & -.648 & .698 \\
\hline
\end{tabular}

Setelah dilakukan rotasi, terlihat jelas variabel yang masuk dalam suatu faktor karena factor loading yang dihasilkan diatas 0,5. Angka-angka yang terdapat pada diagonal, antara Component 1 dengan 1, Component 2 dengan 2 dan Component 3 dengan 3. terlihat ketiga angka diatas 0,5 yaitu berturut-turut 0,$802 ; 0,506 ; 0,698$. Hal ini membuktikan ketiga faktor (Component) yang terbentuk sudah tepat, karena mempunyai korelasi diatas 0,5 .

\subsubsection{Hasil Analisis Faktor}

Hasil analisis faktor dengan rotasi dapat disimpulkan bahwa 9 variabel tersebut dapat direduksi menjadi 3 faktor dan memberi identitas pada masing-masing faktor yaitu:

1. Faktor 1 meliputi Kedisiplinan, Latihan (Training), Kesehatan, Pengalaman kerja diberi nama Faktor Pengalaman Kerja.

2. Faktor 2 meliputi Perilaku, Kompetensi, Potensi diberi nama Faktor Perilaku.

3. Faktor 3 meliputi Tingkat Pendidikan Formal, Jenis Kelamin diberi nama Faktor Pendidikan Formal.

82 Pengaruh Sumber Daya Manusia Terhadap Pengendalian Mutu Jalan (Studi Kasus di Provinsi DIY) (Rossy Armyn Machfudiyanto) 


\subsection{Proses Pembobotan Variabel Pengaruh SDM yang terseleksi}

\subsubsection{Penyusunan Model AHP}

Langkah selanjutnya dalam penelitian ini yaitu melakukan perbandingan antar proyek jalan.

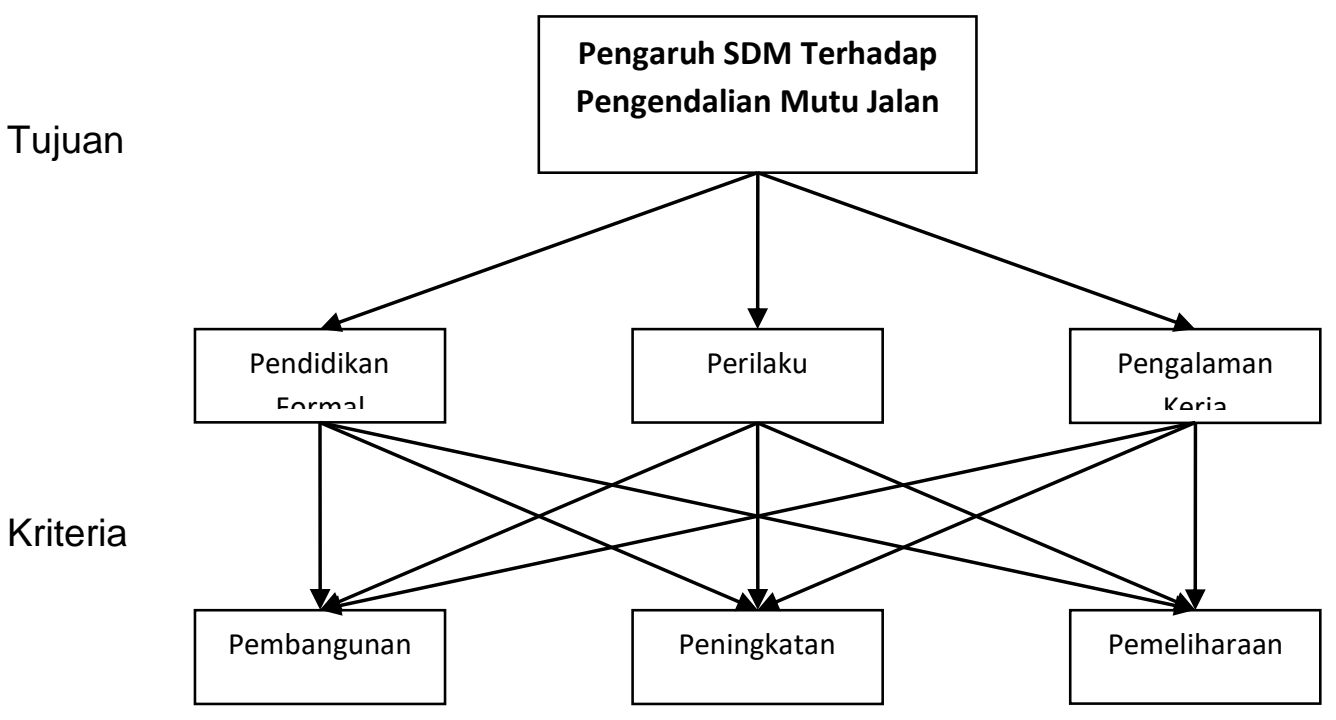

Alternatif

Gambar 2 Penyusunan model AHP untuk variabel pengaruh SDM hasil analisis faktor (kriteria) terhadap alternatif pengendalian mutu jalan

\subsubsection{Pembobotan Kriteria}

Rumus dari rata-rata ukur adalah sebagai berikut:

$$
a w=\sqrt[n]{a 1 x a 2 x a 3 x \ldots x a n}
$$

Dimana $\mathrm{n}$ menyatakan banyaknya responden dan a1 adalah penilaian dari responden kei. Dalam penelitian ini jumlah responden adalah 30 orang.

Perhitungan : untuk perbandingan pendidikan formal dengan perilaku diperoleh rata-rata penilaian dari 30 responden adalah: $\sqrt[30]{7 x 1 \times 1 x . . x 5 \times 1 \times 3}=1,506$

Demikian seterusnya sampai pada perhitungan terakhir. Hasil perbandingan secara berpasangan antara kriteria tersebut akan ditampilkan pada Tabel 5.7

Tabel 11 Matrik perbandingan antar kriteria

\begin{tabular}{|c|c|c|c|}
\hline & $\begin{array}{c}\text { Pendidikan } \\
\text { formal }\end{array}$ & Perilaku & $\begin{array}{c}\text { Pengalaman } \\
\text { Kerja }\end{array}$ \\
\hline Pendidikan formal & 1 & 1,506 & 0,661 \\
\hline Perilaku & 0,664 & 1 & 0,896 \\
\hline Pengalaman Kerja & 1,513 & 1,116 & 1 \\
\hline
\end{tabular}

Perhitungan AHP dilakukan dengan cara melakukan perkalian antar baris, kemudian diakarpangkatkan tiga sehingga diperoleh nilai bobot masing-masing kriteria. 
Analisis perhitungan di bawah ini dilakukan berdasarkan matrik perbandingan antar kriteria di atas:

1. Baris pertama dilakukan perkalian

$1 \times 1,506 \times 0,661=0,995$

Hasil diakar pangkatkan tiga (jumlah baris tiga)

$$
\sqrt[3]{0,995}=0,998
$$

2. Baris kedua dilakukan perkalian

$0,664 \times 1 \times 0,896=0,595$

Hasil diakar pangkatkan tiga (jumlah baris tiga)

$$
\sqrt[3]{0,595}=0,841
$$

3. Baris ketiga dilakukan perkalian

$1,513 \times 1,116 \times 1=1,688$

Hasil diakar pangkatkan tiga (jumlah baris tiga) $\quad \sqrt[3]{1,688}=1,191$

Jumlah total akar pangkat tiga adalah $0,998+0,841+1,191=3,03$

Bobot tiap kriteria didapat akar pangkat tiga dibagi dengan jumlah nilai akar pangkat tiga.

1. Variabel tingkat pendidikan formal

$$
W i=\frac{0,998}{3,03}=0,329
$$

2. Variabel perilaku

$$
W i=\frac{0,841}{3,03}=0,277
$$

3. Variabel pengalaman kerja

$$
W i=\frac{1,191}{3,03}=0,394
$$

\subsubsection{Pembobotan Alternatif}

Tabel 12 Matrik perbandingan antar alternatif ditinjau dari pendidikan formal

\begin{tabular}{|c|c|c|c|}
\hline Pendidikan formal & Pembangunan jalan & Peningkatan jalan & Pemeliharaan jalan \\
\hline Pembangunan jalan & 1 & 0,963 & 0,977 \\
\hline Peningkatan jalan & 1,038 & 1 & 1,038 \\
\hline Pemeliharaan jalan & 1,023 & 0,963 & 1 \\
\hline
\end{tabular}

Pembobotan alternatif ditinjau dari variabel pengaruh pendidikan formal

1. Baris pertama dilakukan perkalian, yaitu $1 \times 0,963 \times 0,977=0,941$

Hasil diakar pangkatkan 3 (jumlah baris 3) , yaitu $\sqrt[3]{0,941}=0,98$

2. Baris kedua dilakukan perkalian, yaitu $1,038 \times 1 \times 1,038=1,077$

Hasil diakar pangkatkan 3 (jumlah baris 3 ) , yaitu $\sqrt[3]{1,077}=1,02$

84 Pengaruh Sumber Daya Manusia Terhadap Pengendalian Mutu Jalan (Studi Kasus di Provinsi DIY) (Rossy Armyn Machfudiyanto) 
3. Baris ketiga dilakukan perkalian, yaitu 1,023 ×0,963 $\times 1=0,985$

Hasil diakar pangkatkan 3 (jumlah baris 3 ) adalah $\sqrt[3]{0,985}=0,99$

Jumlah total akar pangkat 3 adalah 0,98 +1,02 +0,99 =2,99

Bobot tiap alternatif didapat dari hasil normalisasi yaitu akar pangkat 3 dibagi dengan total jumlah nilai akar pangkat 3.

1. Alternatif pembangunan jalan, $W i=\frac{0,98}{2,99}=0,328$

2. Alternatif peningkatan jalan, $W i=\frac{1,02}{2,99}=0,341$

3. Alternatif pemeliharaan jalan, $W i=\frac{0,99}{2,99}=0,331$

Hasil analisis untuk pembobotan matrik perbandingan antar alternatif ditinjau dari segi variabel pengaruh Pendidikan Formal, Perilaku dan Pengalaman Kerja, selengkapnya akan ditampilkan pada Tabel 13

Tabel 13 Matrik perbandingan antar alternatif terhadap masing-masing kriteria

\begin{tabular}{|c|c|c|c|}
\hline & $\begin{array}{c}\text { Pendidikan formal } \\
(32,9 \%)\end{array}$ & $\begin{array}{c}\text { Perilaku } \\
(27,7 \%)\end{array}$ & $\begin{array}{c}\text { Pengalaman Kerja } \\
(39,4 \%)\end{array}$ \\
\hline Pembangunan jalan & 0,328 & 0,347 & 0,359 \\
\hline Peningkatan jalan & 0,341 & 0,330 & 0,329 \\
\hline Pemeliharaan jalan & 0,331 & 0,323 & 0,312 \\
\hline
\end{tabular}

Prioritas-prioritas lokal dan prioritas global dari masalah pengaruh sumber daya manusia terhadap pengendalian mutu jalan ditampilkan pada perkalian matrik sebagai berikut:

$$
\left[\begin{array}{lll}
0,328 & 0,347 & 0,359 \\
0,341 & 0,330 & 0,329 \\
0,331 & 0,323 & 0,312
\end{array}\right] \times\left[\begin{array}{l}
0,329 \\
0,277 \\
0,394
\end{array}\right]=\left[\begin{array}{l}
0,345 \\
0,333 \\
0,322
\end{array}\right]
$$

Tabel 14 Hasil prioritas global

\begin{tabular}{|l|c|}
\hline \multicolumn{1}{|c|}{ Alternatif } & Prioritas Global \\
\hline Pembangunan jalan & 0,345 \\
\hline Peningkatan jalan & 0,333 \\
\hline Pemeliharaan jalan & 0,322 \\
\hline
\end{tabular}

\subsubsection{Uji Konsistensi}

1. Pendidikan formal

$$
\left[\begin{array}{ccc}
1 & 0,963 & 0,977 \\
1,038 & 1 & 1,038 \\
1,023 & 0,963 & 1
\end{array}\right] \times\left[\begin{array}{l}
0,328 \\
0,341 \\
0,331
\end{array}\right]=\left[\begin{array}{c}
0,98 \\
1,02 \\
0,99
\end{array}\right]
$$

$\lambda$ Pendidikan formal:0,98+1,02+0,99=2,99 
2. Perilaku

$$
\left[\begin{array}{ccc}
1 & 1,055 & 1,055 \\
0,948 & 1 & 1,038 \\
0,948 & 0,963 & 1
\end{array}\right] \times\left[\begin{array}{c}
0,347 \\
0,330 \\
0,323
\end{array}\right]=\left[\begin{array}{c}
1,03 \\
0,98 \\
0,97
\end{array}\right]
$$

$\lambda$ Perilaku:1,03+0,98+0,97 = 2,98

3. Pengalaman kerja

$$
\left[\begin{array}{ccc}
1 & 1,126 & 1,107 \\
0,888 & 1 & 1,094 \\
0,903 & 0,914 & 1
\end{array}\right] \times\left[\begin{array}{l}
0,359 \\
0,329 \\
0,312
\end{array}\right]=\left[\begin{array}{c}
1,07 \\
0,99 \\
0,94
\end{array}\right]
$$

$\lambda$ Pengalaman kerja: $1,07+0,99+0,95=3,01$, Jadi Eigenvalue maksimum didapat $(\lambda$ maks $)=3,01$.

Pengukuran konsistensi dari suatu matrik didasarkan atas suatu eigenvalue maksimum. Dengan eigenvalue maksimum, inkonsistensi yang bisa dihasilkan matrik perbandingan, dapat diminimumkan. Makin dekat eigenvalue maksimum dengan besarnya matrik, maka makin konsisten matrik tersebut.

$$
C I=\frac{(\lambda m a k s-n)}{(n-1)} \quad, \text { dengan } \mathrm{n}=3, \text { maka } C I=\frac{(3,01-3)}{(3-1)}=0,005
$$

Indeks konsistensi kemudian diubah dalam bentuk rasio inkonsistensi dengan cara membaginya dengan suatu indeks random.

$$
C R=\frac{C I}{R I}=\frac{0,005}{0,58}=0,00862(<0,1 \rightarrow \text { Konsisten })
$$

\subsubsection{Pembahasan}

Hasil matrik perbandingan antar variabel pengaruh sumber daya manusia diatas dapat disimpulkan bahwa penilaian dalam matrik tersebut masih diterima inkonsistensinya. Hal ini terlihat inkonsistensi matrik tersebut sekitar 0,005 masih dibawah $10 \%$ yang merupakan batas kritis konsistensi. Hasil matrik itu sendiri menunjukkan urutan variabel pengaruh sumber daya manusia yaitu pengalaman kerja $(39,4 \%)$, tingkat pendidikan formal $(32,9 \%)$ dan perilaku (27,7\%). Hasil penelitian diperoleh $\mathrm{CR}=0,00862<0,1$ sehingga dapat disimpulkan bahwa jawaban dari para responden adalah konsisten. Oleh karena itu perhitungan bobot prioritas variabel pengaruh (kriteria) sumber daya manusia terhadap alternatif dalam pengendalian mutu jalan dapat dipertanggungjawabkan.

\section{KESIMPULAN DAN SARAN}

\subsection{Kesimpulan}

Hasil penelitian diperoleh dari sebelas variabel pengaruh SDM yang terbentuk yang kemudian diseleksi menggunakan metode Analisis Faktor didapatkan sembilan variabel pengaruh SDM terseleksi yang telah dikelompokkan menjadi tiga faktor yaitu:

1. Faktor 1 meliputi kedisiplinan, latihan (training), kesehatan, pengalaman kerja diberi nama faktor pengalaman kerja.

2. Faktor 2 meliputi perilaku, kompetensi, potensi diberi nama faktor perilaku.

3. Faktor 3 meliputi tingkat pendidikan formal, jenis kelamin diberi nama faktor pendidikan formal.

Hasil penelitian diperoleh bobot prioritas masing-masing kriteria terhadap tujuan SDM untuk mengendalikan mutu jalan sebagai berikut pendidikan formal sebesar $32,9 \%$;

86 Pengaruh Sumber Daya Manusia Terhadap Pengendalian Mutu Jalan (Studi Kasus di Provinsi DIY) (Rossy Armyn Machfudiyanto) 
perilaku 27,7 \% ; dan pengalaman kerja $=39,4 \%$ Pembobotan alternatif dalam pengendalian mutu jalan yang meliputi pembangunan jalan, peningkatan jalan, pemeliharaan jalan ditinjau dari variabel pengaruh SDM yang terseleksi diperoleh hasil yang hampir sama akan tetapi bobot prioritas yang terbesar terdapat pada pembangunan jalan sebesar $34,5 \%$ diikuti dengan peningkatan jalan sebesar $33,3 \%$ dan pemeliharaan jalan sebesar $32,2 \%$.

\subsection{Saran}

Penggunaan metode AHP ini relatif masih baru, dengan demikian diharapkan metode AHP dapat digunakan dalam proses pengambilan keputusan sehari-hari berdasarkan bentuk hirarki yang sudah ada. Selain itu pemakaian metode AHP ini dapat lebih disebarkan di Indonesia yang secara umum mengalami kondisi kurang baiknya data sekunder atau data yang kurang dapat dijamin validitasnya.

\section{DAFTAR PUSTAKA}

Ancok, D., 2004. Psikologi Terapan: Mengupas Dinamika Kehidupan Manusia. Penerbit Darussalam, Yogyakarta.

Hurlock, Elizabeth B., 1978. Child Development, Sixth Edition. McGraw-Hill, Inc.

Hurlock, Elizabeth B., 1980. Development Psychology: A Life-Span Approach, Fifth Edition. McGraw-Hill, Inc.

Komputer, W., 2004. Pengolahan Data Statistik dengan SPSS 12. Penerbit ANDI OFFSET, Yogyakarta.

Koster, W. 2001. Faktor-Faktor yang Mempengaruhi Produktivitas Pegawai. Jurnal Pendidikan dan Kebudayaan Indonesia, hal 1-3. www.pdk.go.id/Jurnal/29/ Survei\%20di\%20PT\%20Asuransi\%20Akenlife. Pusat data dan Informasi Pendidikan Departemen Pendidikan Nasional, Jakarta.

Permadi, B. S., 1992. AHP. Departemen Pendidikan dan Kebudayaan Pusat Antar Studi Fakultas Ekonomi Universitas Indonesia, Jakarta.

Poerwadarminta, W. J. S., 1982. Kamus Umum Bahasa Indonesia. Penerbit Balai Pustaka, Jakarta.

Rostianti, I., 2003. Pemilihan Jalur Selatan di Propinsi Daerah Istimewa Yogyakarta dengan metode Analytical Hierarchy Process. Program S-1 Ekstensi Jurusan Teknik Sipil Fakultas Teknik Universitas Gadjah Mada, Yogyakarta.

Saaty, Thomas L., 1990. Decision Making For Leaders: The Analytic Hierarchy Process in A Complex World. University of Pittsburgh.

Satriawan, R. H., 2001. Tinjauan Berbagai Alternatif jalur Tream Listrik di Yogyakarta. Program S-1 Reguler Jurusan Teknik Sipil Fakultas Teknik Universitas Gadjah Mada, Yogyakarta.

Sumarsono, H. M. S., 2004. Metode Riset Sumber Daya Manusia. Penerbit GRAHA ILMU, Yogyakarta.

Walgito, B. 1990., Psikologi Sosial (Suatu Pengantar). Penerbit ANDI OFFSET, Yogyakarta. 